\title{
The main aspects of professional training of students in a pandemic
}

\author{
Os principais aspectos da formação profissional de alunos \\ em uma pandemia
}

\section{Los principales aspectos de la formación profesional de los estudiantes en una pandemia}

\author{
Roma Sybirna1 (iD), Tetiana Fursykova² iD, Ganna Polishchuk² (iD, \\ Oleksandr Balanutsa ${ }^{3}$ iD, Alla Marchuk ${ }^{1}$ iD
}

${ }^{1}$ Lviv State University of Internal Affairs, Lviv, Ukraine.

${ }^{2}$ Volodymyr Vynnychenko Central Ukrainian State Pedagogical University, Lviv, Ukraine.

${ }^{3}$ Ukraine to the State of Kuwait, Lviv, Ukraine.

Corresponding author:

Roma Sybirna

Email: journaltm@ukr.net

How to cite: Sybirna, R., Fursykova, T., Polishchuk, G., Balanutsa, O., \& Marchuk, A. (2021). The main aspects of professional training of students in a pandemic. Revista Tempos e Espaços em Educação, 14(33), e16583.

http://dx.doi.org/10.20952/revtee.v14i33.16583

\begin{abstract}
The main purpose of the study is to analyze the main aspects of professional training of students in a pandemic. In modern conditions, an important place is given to the integration of science, education and innovation. University education is designed to provide systemic knowledge about the professional field of activity, its specifics and should form the personal qualities of a specialist. It is assumed that this is one of the decisive factors in the development of the economy and society. The need for highly qualified and proactive workers is exacerbated in new conditions, where the issues of professional and practical training and education of a competitive specialist during their studies at higher educational institutions are of particular importance. The development of university education provides for the acquisition of such a quality that meets the needs of the student's personality, the requirements of society and ensures integration into the global educational space. In modern market conditions, the following requirements are imposed on them: a high level of theoretical training, the prevailing level of social maturity, high efficiency in situations of uncertainty, quick adaptation to the working environment. The study was carried out using the following theoretical methods: systems analysis and synthesis, induction and deduction, comparison, classification, generalization and systematization, idealization and abstraction. Based on the results of the study, the key aspects of professional training of students in a pandemic have been determined.
\end{abstract}

Keywords: Educational process. Methods of teaching. Pedagogy. Problems of training. Students. 


\section{RESUMO}

O objetivo principal do estudo é analisar os principais aspectos da formação profissional de alunos em situação de pandemia. Nas condições modernas, um lugar importante é dado à integração entre ciência, educação e inovação. A formação universitária visa proporcionar conhecimentos sistêmicos sobre o campo de atuação profissional, suas especificidades e deve constituir as qualidades pessoais de um especialista. Parte-se do pressuposto de que este é um dos fatores decisivos para o desenvolvimento da economia e da sociedade. A necessidade de trabalhadores altamente qualificados e pró-ativos é exacerbada em novas condições, onde as questões de formação profissional e prática e educação de um especialista competitivo durante seus estudos em instituições de ensino superior são de particular importância. $O$ desenvolvimento da educação universitária prevê a aquisição de uma qualidade que atenda às necessidades da personalidade do aluno, às exigências da sociedade e garanta a integração no espaço educacional global. Nas condições de mercado modernas, os seguintes requisitos são impostos: um alto nível de formação teórica, o nível de maturidade social prevalecente, alta eficiência em situações de incerteza, rápida adaptação ao ambiente de trabalho. $O$ estudo foi realizado utilizando os seguintes métodos teóricos: análise e síntese de sistemas, indução e dedução, comparação, classificação, generalização e sistematização, idealização e abstração. Com base nos resultados do estudo, foram determinados os principais aspectos da formação profissional de estudantes em uma pandemia.

Palavras-chave: Alunos. Métodos de ensino. Pedagogia. Problemas de formação. Processo educacional.

\section{RESUMEN}

El objetivo principal del estudio es analizar los principales aspectos de la formación profesional de los estudiantes en una pandemia. En las condiciones modernas, se le da un lugar importante a la integración de la ciencia, la educación y la innovación. La educación universitaria está diseñada para proporcionar un conocimiento sistémico sobre el campo de actividad profesional, sus particularidades y debe formar las cualidades personales de un especialista. Se asume que este es uno de los factores decisivos en el desarrollo de la economía y la sociedad. La necesidad de trabajadores altamente calificados y proactivos se agrava en las nuevas condiciones, donde las cuestiones de la formación profesional y práctica y la educación de un especialista competitivo durante sus estudios en las instituciones de educación superior son de particular importancia. El desarrollo de la formación universitaria prevé la adquisición de una calidad tal que responda a las necesidades de la personalidad del estudiante, los requerimientos de la sociedad y asegure la integración en el espacio educativo global. En las condiciones del mercado moderno, se les imponen los siguientes requisitos: un alto nivel de formación teórica, el nivel de madurez social imperante, alta eficiencia en situaciones de incertidumbre, rápida adaptación al entorno laboral. El estudio se realizó utilizando los siguientes métodos teóricos: análisis y síntesis de sistemas, inducción y deducción, comparación, clasificación, generalización y sistematización, idealización y abstracción. A partir de los resultados del estudio, se han determinado los aspectos clave de la formación profesional de los estudiantes en una pandemia.

Palabras clave: Alumnos. Métodos de enseñanza. Pedagogía. Problemas de formación. Proceso educativo.

\section{INTRODUCTION}

For successful work in the chosen specialty, a modern young specialist, along with deep theoretical knowledge, must have the necessary skills and abilities for their effective application in practice. This is achieved through practical training of students in the learning process. So, practical training, along with studies and independent work, is one of the important forms of organizing the educational process, the quality of which determines the competitiveness of university graduates 
in the labor market. Attaching great importance to the practical training of future specialists, the university council approved the Concept of the practical training of students for the entire period of study. It provides for close interaction of departments, a scientific and educational center and a communication center "of relations with production with enterprises and organizations - bases of practice.

To improve the practical training of future specialists, a new procedure for passing practice is called upon, which provides for internships for students in positions related to future work. Determination and selection of appropriate jobs is one of the urgent tasks of the teachers of the department.

Professional training of a future specialist is a pedagogical process of university education, the result of which is the formation and development of his professional readiness. It manifests itself in forms of activity and determines the ability to set professional goals for oneself, choose ways to achieve them, exercise self-control over the performance of one's own actions and predict ways to increase work productivity in a professional direction. All this is formed with the help of higher education standards, for the development of this specialty and the student's personal qualities.

Paying attention to the need to prepare students for practical activities, it is impossible to ignore the fact that the current state of society, the characteristic features of which are the processes of globalization and social integration, informatization, leaves less and less opportunity for advancement for those specialists who do not have computer equipment and information technologies. the ability to use foreign sources. Thus, the preparation of students for practical working conditions at enterprises should be combined with equipping higher school students with modern knowledge of computer technology, as well as communication skills in foreign languages. Another component of the formation of a competitive specialist in the labor market is his practical training in production. It is advisable to consider in more detail precisely its role in the formation of the professional competence of future specialists, since during the industrial practice their professional skills and personal qualities are formed, and it also prepares future specialists for independent performance of duties in the first position where they will work. During the internship, the student can test his professionalism. And also, has the ability to study real situations; check the knowledge gained during training; independently make decisions, justifying their appropriateness in front of the head of the practice. The future specialist learns subordination, teamwork, and gains professional communication skills (Cordeiro et. al., 2021; Fedorov et. al., 2021).

The organization of practical professional training of future specialists in higher educational institutions is carried out both in the study of professionally oriented theoretical disciplines and in industrial practice. University education is based on the training of highly professional and creative specialists who are able to adapt to the modern requirements of the economy and the labor market.

The introduction of quarantine gave an impetus to the search for new effective remote forms of work with applicants for higher education. In these conditions, it is not enough just to issue a task and receive an answer. It is necessary to establish communication with students: provide advice, help in completing assignments. Therefore, the success of work under quarantine conditions depends on the active interaction of all participants in the educational process, the quality and speed of Internet traffic, the availability of technical capabilities and, above all, the skills of teachers and applicants for higher education in the use of modern information and digital technologies.

\section{METHODOLOGY}

The main purpose of the study is to analyze the main aspects of professional training of students in a pandemic. In modern conditions, an important place is given to the integration of science, education and innovation. For this, a number of methods were applied, which form the research methodology. The study was carried out using the following theoretical methods: systems 
analysis and synthesis, induction and deduction, comparison, classification, generalization and systematization, idealization and abstraction.

\section{RESULTS AND DISCUSSION}

Note that in traditional teaching, the teacher is the interpreter of knowledge, while in distance learning, another information model is used, according to which the student becomes the interpreter of knowledge, and the teacher plays the role of a consultant and coordinator of the learning process. Then the principle of self-educational activity acquires a decisive importance and predetermines the use of a search approach in the development of a process-oriented informational model of distance learning, which provides for: immersion of students who are ready for independent cognitive activity into an active educational environment "human-computer"; introduction of a subject-figurative style as a leading one in an active educational environment (it is not the book itself that is transmitted through the information channel, but the image of the object, its properties, ensures the perception of information in a holistic manner as the perception of the image); transition from verbal-logical, analytical thinking to synthetic, figurative, intuitive and situational thinking (Fedorov et. al., 2017; Gruzdeva et. al., 2018; Kovalevskaia et. al., 2021).

It is important in distance learning that the use of new communication technologies provides an opportunity for interactive interaction of participants in the learning process, and the availability of modern interactive training and control tools (computer programs, interactive video discs, information bases and access to them via the Internet, etc.) organize training in accordance with modern principles of didactics. Experience shows that distance learning is a challenge not only for students, but also for teachers, and it is not easy to organize high-quality professional training of applicants for higher education online. Let us dwell on certain aspects of the professional training of future teachers in the conditions of quarantine.

With distance learning, the active role of the teacher does not decrease, since he must determine the level of knowledge of the applicant, and make a decision to adjust the training program in order to achieve the best assimilation of the passed material. If necessary, the student can receive advisory assistance from the teacher, communicating with him online directly on the Internet as a means of communication (web chat, IRC, ICQ, interactive TV, web telephony). Communication online allows you to intensify the educational and cognitive activities of applicants for higher education, contributes to the development of their educational dialogue and interaction. They have the opportunity to discuss any topic that interests them with students and teachers from different cities with whom they communicate online. Distance learning should be perceived not as a real rival to traditional university education, but as one of the newest achievements of information technology, which can potentially change the nature of educational practices that have developed over centuries, expanding and supplementing the capabilities of the classical education system. Among the technical ways of implementing distance learning in higher education institutions, the most popular are: providing access to electronic content for applicants for higher education using the Internet on the basis of their own server or using Internet services that provide the ability to exchange content, such as: Google, MS OneDrive, Yandex drive, etc .; organization of distance learning using additional features of Internet services and the active use of e-mail, personal sites (blogs), social networks (Facebook,). Content is posted on its own server or "cloud" using free mail (social networks) and free tools for creating online tests; use of specialized software, which includes: Moodle, eFront, Edmodo, Blackboard, SuccessFactors, SkillSoft, Litmos, OpenEDX, etc.

When using distance learning tools, it is important to control the assimilation of the material and assess the knowledge of students. Accordingly, teachers need to ensure that it is carried out in one of the possible ways or a combination of them: a written assessment of the level of knowledge of students by electronic testing or by performing open tasks and sending the results by e-mail; orally video conference with students using external platforms. Another form of distance learning 
is the webinar, a special kind of webinar. Webinar services, such as BigBlueButton, WiZiQ or DimDim, ZOOM, GoogIMeet, to expand the possibilities of conducting classroom classes, attracting students from around the world. We have proposed holding two webinars on the topics "Elements of STEAM education in primary school", "Educational environment as a factor in personality development". Webinars allow you to conduct online presentations, collaborate with documents and applications, synchronously view sites, videos and images. Such technologies are used for online meetings and cooperation of teachers and students in real time via the Internet.

We also focus on the fact that modern distance learning is based on the use of: web story documents with a unique address (URL), usually organized in the form of hypertext with the inclusion of text, graphics, sounds, video or animation; websites - a set of web pages, united in meaning, navigationally and physically located on one web server. entries added regularly containing text, images, or multimedia; online diary with comments; web forums (eng. www conference, synonyms - conference, web conference), which serve as a tool for organizing communication on the Internet site; chat (English chat - conversation) - a page where you can chat with other students in real time; Skype is a computer program with which you can make free calls over the Internet, establish conference calls, video calls, and transfer text messages and files; video and teleconferencing - interactive tools that include audio, video, computer and communication technologies for communication between geographically remote interlocutors "face to face" in real time. In the process of mastering the educational material, it is advisable to use thematic forums where you can leave questions and comments (Küçükgöz, 2021; Markova et. al., 2018; Natalia et. al., 2020; Oreshkina et. al., 2021).

The relevance of the studied problem is due to the fact that in the conditions of the formation of the labor market and its saturation with employees of the economic direction, it is difficult for a young specialist to take a worthy place in industrial relations. It has been determined that the main reason is insufficient practical training of students, which would provide an expansion of the volume of basic concepts in the financial and credit sphere, and form the economic thinking of future specialists. At the same time, the market is in need of qualified specialists familiar with modern scientific theories and legislation and familiar with the economic aspects of the organization's practical activities. Consequently, the goal of educational institutions should be not so much the training of personnel with deep knowledge as deeply motivated specialists with developed professional skills, ready to perform mental or physical actions corresponding to the specialty; creative individuals who are able to analyze socio-economic changes in society and develop long-term development programs for both an individual enterprise and an industry or state.

Today, the tasks of training a new type of employee with professional flexibility and mobility, that is, the ability, if necessary, to quickly retrain or change profession, are coming to the fore.

Higher education can be recognized as being of high quality in terms of meeting the needs and requirements of an individual as a consumer of educational services, a customer-employer, the state and the world educational and scientific community. A consumer of educational services shall recognize higher education as of high quality only when this education will guarantee him, as an individual, the realization of his own abilities, obtaining modern knowledge, skills and abilities, a sufficient level of remuneration, and competitiveness as a specialist in the labor market. The customer-employer demands from the specialist high, competence, readiness for high-performance activities aimed at achieving competitiveness by the enterprise. The state seeks through higher education to ensure the formation and expanded reproduction of the intellectual potential of the nation.

An important component of the quality of higher education and the competitiveness of university graduates is vocational training, which is a necessary prerequisite for employment of graduates and is aimed at protecting against unemployment. High competition in the labor market forces us to develop new mechanisms for cooperation with industry enterprises, establish new 
relationships with employers, and practice training a specialist commissioned by business structures to increase the effectiveness of training. As for the knowledge of professional activity, while studying in higher educational institutions, students receive a thorough theoretical training in economic disciplines and disciplines that are adjacent to the data indicated in the curriculum for training these specialists (Prokhorova \& Sedykh, 2016; Sukhodimtseva et. al., 2021; Sydorenko et. al., 2020; Zeer \& Symanyuk, 2014).

An important element of the implementation of the competence-based approach is educational practice as the initial stage of familiarizing students with the chosen specialty, with modern technologies used in enterprises and organizations, obtaining professional knowledge and skills that will help in the study of theoretical courses. Educational and familiarization practice, which is carried out in the first year, lays the foundations for practical work in institutions, organizations, at enterprises of various forms of ownership. After all, knowledge of the basics of ethics of business communication, culture and quality of customer service, the ability to create a consolidated team and work in a team; acquaintance of students with the peculiarities of the organization of jobs in institutions, at enterprises; the procedure for processing business documents of business entities; observance of language norms in the preparation of business documentation is the basis for the training of a competitive specialist. At the same time, the practice provides a professional orientation for the teaching of social and humanitarian disciplines; fixes the most important sections of the main disciplines of the department.

The foundation for research, scientific work is the educational practice of the II course. During its study, students acquire the ability to independently analyze economic problems, using knowledge of the market economy; determine and substantiate their scientific position, work with scientific literature; analyze socio-economic phenomena and processes based on statistical information. The obtained theoretical knowledge and skills are consolidated during educational and introductory practice in the third year, conducted taking into account the specifics of the disciplines of the vocational training cycle. She introduces students to related specialties; demonstrates the relationship between the subjects that are presented; allows you to systematize all your knowledge into a single whole with the aim of a comprehensive vision of the system.

In modern conditions of transformation of all spheres of public relations, especially in the economic system, such a final stage of training under the bachelor's program as professional practice (technological, operational, design, accounting and analytical, economic, etc.) is extremely important. The task of industrial practice is to expand, deepen and consolidate the theoretical knowledge that students received when studying a cycle of special theoretical disciplines and the formation of skills for the practical application of this knowledge in production conditions; acquisition and improvement of professional skills; familiarization with the production process and the production cycle directly in the institution, as well as the collection of factual material for the implementation of course projects.

Undergraduate industrial practice is the final stage of practical training and a preparatory stage for the performance of graduate work. It is carried out in the graduating course with the aim of generalizing and improving the knowledge gained, practical skills and abilities, mastering professional experience and the readiness of students for independent work.

It is advisable to note that with the advent of the latest teaching aids and, first of all, the Internet and various information technologies, the cognitive possibilities of practical training of students have greatly increased, its role in the formation of a specialist has significantly increased. After all, the use of information and computer technologies to optimize the mastery of new economic concepts by students makes it possible to visually teach the material, expands the search environment for the necessary economic information, transfers professional communication to a new level - web communication, significantly reduces the time spent on testing the formed knowledge of students' professional training, gives the opportunity for the teacher to develop 
creative tasks, thereby contributing to the development of students' creativity. According to the effectiveness of the educational process, it is ensured by the latest methods, modern pedagogical and information technologies, namely: multimedia technologies, elements of a business game, training, situational exercises, case methods. It is role-playing and business games that provide the organization of training through imitation of situations of a professional direction, in which students can feel the "burden of responsibilities" and responsibility for the decisions made; is a kind of problem learning, since it is aimed at solving the assigned tasks, finding the right solutions, solving professional problems; provide an opportunity to check the level of knowledge of students; form the professional competence of future specialists.

The combination of theoretical and practical training, the integration of training with research and experimental work, contribute to the practical orientation of training, the active search and implementation of non-traditional forms and methods of teaching students, the formation of an integral personality of future specialists. Such specialists, with diplomas of higher education and acquired and developed abilities for continuous self-learning throughout life, are needed not only in small and medium-sized businesses, but also in other institutions and organizations.

The phenomenon of social education is important for the professional training of future specialists and is one of the most relevant and debatable in scientific circles. This phenomenon requires from specialists in the field of social / remedial education the ability and ability to carry out not only basic educational activities, but also additional ones, the effectiveness of which is due to civic stance and the desire to activate personal resources. However, modern professional training of students for their future profession does not sufficiently take into account the specifics of social work and the characteristics of the motivational sphere of students: the need for active forms of self-realization, openness to new experience, the desire to be useful to people and provide timely assistance to those who need it. Consequently, there is a need for a special organization of the educational process in a higher educational institution, based on philanthropic, activity-oriented, personality-oriented approaches that contribute to the formation of the readiness of future specialists in the field of pedagogical activity in volunteer work. The participation of students in the public life of society requires their preparation for volunteer activities, which can be effectively carried out in a higher educational institution thanks to classroom and extracurricular forms of educational work.

We believe that extracurricular work with students should have a professionally oriented nature, which we understand as the creation of educational and pedagogical situations on a volunteer topic, the complexity of which is gradually increasing taking into account the variety of forms and methods of volunteer work, which requires students to show independence, volitional tension, emotional mood for solving the proposed problems. The organization of extracurricular work is carried out by means of volunteer work through disputes, evenings, press conferences on topical issues of volunteering, competitions, oral journals of volunteer topics, as well as due to the activities of the school of volunteers. With the proper organization of extracurricular work, students have the opportunity to gain practical experience in volunteer work, to form the skills of independent action, to search for their own professional style of activity. An important condition is the systematic nature of extracurricular activities and their connection with educational and practical volunteer work.

The dynamic processes taking place in the political, economic and socio-cultural spheres of modern society put forward new requirements for the professional training of specialists, provide for the maximum approximation of the training and education of students with the demands of the time, the disclosure of abilities and the creation of conditions for the development of their creative activity. It is not enough for modern professionals to have deep subject knowledge and practical skills. 
In modern conditions of development of professional education in pedagogical science, new concepts appear, traditional and established ones are filled with new content, some become outdated, since they are not tested in practice. All this creates difficulties in research work and teaching practice. This is due to the fact that professional pedagogy is a complex science that not only generates new terms, but also synthesizes the conceptual apparatus of related sciences: cultural studies, sociology, psychology, physiology, economics, law, ethics, etc. Integration processes have a significant impact on its terminology. inherent in both theory and practice of vocational education. First of all, this concerns the integration of professional pedagogy, culture, sociology, economics, professions, technology, production; it manifests itself in the interpenetration, on a single methodological basis, of pedagogical knowledge in cultural, sociological, legal, economic and other studies. Such mutual enrichment is also necessary in the aspect of research into the effectiveness and reliability of a specialist's professional activity.

The need to reorient educational policy towards the formation of a modern specialistresearcher is clearly traced. One of the distinctive features of the latter is a change in the status of science, the introduction of a new integrative function, provides for the intensive use of scientific knowledge in various spheres of human life, a change in the nature of scientific activity, research into the development of science in a cultural and historical context, the humanization of science and a rethinking of its role and place in development humanity, etc.

The competence of a specialist is such a characteristic of his qualifications, which presents the knowledge, skills and qualities necessary for the implementation of professional activities. The very interpretation of this concept reflects his ability to apply the knowledge gained to the subject of professional activity. Bearing in mind the subject of the teacher's professional activity, we can say that his competence characterizes scientific knowledge from one or several academic disciplines; disciplines related to knowledge about a person (psychology, pedagogy, sociology, anthropology, physiology, etc.), humanitarian disciplines (philosophy, history, etc.) the necessary knowledge of management theory, since the teacher performs managerial functions. In addition, the specificity of the activity requires the teacher to know the basics of self-education, as well as a certain pedagogical experience of others.

Professional morality is such a characteristic of a specialist, which reflects personal, spiritual and spiritual qualities, has a manifestation in the process of professional activity and determines its essence, and also affects its results. Morality includes such spiritual (intellectual) and mental (sensory) qualities, thanks to which specialists manifest themselves in professional activities. Their internal acceptance of socially valuable ethical norms and rules helps to remove the contradictions between personal and social needs. Competence and morality determine the pedagogical culture a set of pedagogical values, has an impact in the teacher's professional activity and behavior and in their results.

It should also be noted that a high level of professionalism of a specialist, including a teacher, is ensured by a reliable professional activity. Organization of professional training of future specialists is based on the principles of modern higher education: the unity of teaching and upbringing; the orientation of the learning process in a higher educational institution on the harmonious development of the student's personality; purposefulness and scientific character; humanization of education; provision of culture-like appearance; the unity of educational, developmental and educational functions of training; activity and creative independence of students and their responsibility for the results of educational and cognitive activities; systematicity and consistency in the process of educational activities of the teacher and independent work of the student. It should be noted that a mandatory requirement for the construction of the educational process in higher education should be a harmonious combination of research and educational and cognitive activities of students, which presupposes such an organization of the educational process that is capable of ensuring the formation of a humane personality of a future specialist capable of 
creative professional activity. In this regard, it is necessary to attract students to participate in scientific circles, olympiads, creative competitions, artistic and creative teams, to conduct scientific research, thus stimulating the development of their creative abilities.

\section{CONCLUSION}

Vocational education is the leading concept and educational and organizational reality of the modern stage of education development, associated with the construction of end-to-end consistent lines in the training and retraining of specialists, highlighting the stages of such training, ensuring the integration of educational systems of various levels and the structural and logical relationship of general educational, fundamental and special disciplines in In the new model of sustainable development of society, the advanced development of human quality, the quality of education, and the quality of vocational education become an absolute necessity. The success of the development of the content and technologies of vocational training largely depends on the effectiveness of reducing the discrepancy between the quality of education and the requirements imposed on it by employers and the labor market. In this case, the problem of increasing the responsibility of educational institutions for the final results of educational activities acquires special relevance. Among the priorities identified by its social partners in front of professional education, a special place is given to ensuring the proper quality of training of specialists.

So, the professional training of future specialists is characterized by polyaspectrum and presupposes the assimilation of fundamental knowledge, the formation of readiness for their creative practical application, the development of personal qualities, in the aggregate, ensures the readiness of graduates of educational institutions to successfully fulfill their professional functions.

The research carried out allows us to conclude that the combination of traditional and distance learning contributes to expanding the educational opportunities of future teachers by increasing the availability and flexibility of training, taking into account the individual characteristics and educational needs of applicants for higher education, as well as the pace and rhythm of learning the educational material and the formation of media literacy. At the same time, the professional training of future teachers in quarantine is aimed at a deep understanding of the educational material, the formation of communicative, informational competencies, and distance learning tools make it possible to receive educational services in conditions safe for life and health. In addition, distance learning also performs an educational function - it contributes to the formation of independence, self-improvement and creativity. Also, students use the opportunity to use educational platforms and services that are open for the period of quarantine around the world, which helps to increase their motivation for learning, independence, reflection and introspection. In the long term, distance education will make learning in higher education institutions a carefully planned and exciting learning process.

The study was carried out using the following theoretical methods: systems analysis and synthesis, induction and deduction, comparison, classification, generalization and systematization, idealization and abstraction. Based on the results of the study, the key aspects of professional training of students in a pandemic have been determined. Promising areas for further research are aspects of the development of the digital culture of future teachers in the context of the globalizing digital space.

Authors' Contributions: Sybirna, R.: conception and design, acquisition of data, drafting the article, critical review of important intellectual content; Fursykova, T.: conception and design, acquisition of data, drafting the article, critical review of important intellectual content; Polishchuk, G.: conception and design, acquisition of data, drafting the article, critical review of important intellectual content; Balanutsa, O.: conception and design, acquisition of data, drafting the article, critical review of important intellectual content; Marchuk, A.: conception and design, acquisition of data, drafting the article, critical review of important intellectual content. All authors have read and approved the final version of the manuscript. 
Ethics Approval: Not applicable.

Acknowledgments: Not applicable.

\section{REFERENCES}

Cordeiro, E. P. B., Marques, M. M. C., \& Costa, M. T. N. (2021). Socio-emotional education: paths to inspire studies, research and practices. Revista Tempos e Espaços em Educação, 14(33), e13729.

https://doi.org/10.20952/revtee.v14i33.13729

Fedorov, A. A., Mialkina, E. V., Sedykh, E. P. S., \& Zhitkova, V. A. (2021). Model of managing the professionaleducational route of a future specialist. Revista Tempos e Espaços em Educação, 14(33), e16325. https://doi.org/10.20952/revtee.v14i33.16325

Fedorov, A.A., Paputkova, G.A., Ilaltdinova, E.Y.,Filchenkova, I.F., \& Solovyev, M.Y. (2017). Model for employersponsored education of teachers: opportunities and challenges. Man in India, 97(11), 101-114.

Gruzdeva, M.L., Prokhorova, O.N., Chanchina, A.V., Chelnokova, E.A., \& Khanzhina, E.V. (2018). Post-graduate information support for graduates of pedagogical universities. Advances in Intelligent Systems and Computing, 622, 143-151.

Kovalevskaia, N., Gilyazeva, E. N., Lobazova, O. F., Duborkina, I. A., \& Sokolova, A. P. (2021). Impact of digital services of hybrid cloud-based learning environment on efficiency of education. Revista Tempos e Espaços em Educação, 14(33), e15297. https://doi.org/10.20952/revtee.v14i33.15297

Küçükgöz, M. (2021). The effect of paternalist leadership style of principals on the professional burnout of special education teachers. Revista Tempos e Espaços em Educação, 14(33), e16089. https://doi.org/10.20952/revtee.v14i33.16089

Markova, S.M., Sedykh, E.P., Tsyplakova, S.A., \& Polunin, V.Y. (2018). Perspective trends ofdevelopment of professional pedagogics as a science. Advances in Intelligent Systems and Computing, 622, 129-135.

Natalia, S., Veronika, D., Nataliia, B., \& Iryna, H. (2020). Formation of professional competencies of primary school teachers using ICT. Revista Tempos e Espaços em Educação, 13(32), 1-17.

https://doi.org/10.20952/revtee.v13i32.14965

Oreshkina, A. K., Lukashenko, D. V., Samokhin, I. S., \& Sergeeva, M. G. (2021). Digital educational environment as a factor of developing teacher's professional reflection. Revista Tempos e Espaços em Educação, 14(33), e16166. https://doi.org/10.20952/revtee.v14i33.16166

Prokhorova, M.P., \& Sedykh,E.P. (2016).Designing an individual educational route for a bachelor in the process of mastering managerial disciplines. Azimuth of Scientific Research: Pedagogy and Psychology, 3(16), 124-127.

Sukhodimtseva, A., Sergeeva, M., Lukashenko, D., \& Pyankov, M. (2021). The methodology of the creation of a flowchart of teacher professional development programme in functional literacy aspect. Revista Tempos e Espaços em Educação, 14(33), e15525. https://doi.org/10.20952/revtee.v14i33.15525

Sydorenko, V., Shorobura, I., Ponomarenko, A., Dei, M., \& Dzhus, O. (2020). Application of technologies of formal and non-formal education for continuous professional development of the modern specialist. Revista Tempos e Espaços em Educação, 13(32), 1-24. https://doi.org/10.20952/revtee.v13i32.14729

Zeer, E.F., \& Symanyuk, E.E. (2014). Theoretical and applied bases for predicting personal professional future. Fundamental Research, 9(8), 1863-1869.

Received: 31 July 2021 | Accepted: 22 September 2021 | Published: 17 November 2021 